JEL-класифікація: M 41

УДК 657.37

https://doi.org/10.31713/ve1201813

Левицька С. О., д.е.н., професор, Сич Д. М., аспірант (Національний університет водного господарства та природокористування, м. Рівне)

\title{
ІНФОРМАТИВНІСТЬ ЕКОНОМІЧНОГО АНАЛІЗУ В СИСТЕМІ УПРАВЛІНСЬКОГО ОБЛІКУ
}

Статтю присвячено вивченню питань практичного застосування інструментарію управлінського аналізу фінансових результатів діяльності виробничих підприємств України. Узагальнено методику та організацію зазначеного виду економічного аналізу за даними управлінського обліку. Розкрито фактори формування необхідного рівня деталізації та цільової направленості аналітичних процедур. Розглянуто міжнародну практику функціонування центрів відповідальності за пріоритетними напрямками розвитку бізнесу, альтернативні методи калькуляції собівартості готової продукції. Формування виважених, оперативних та повних причинно-наслідкових тенденцій, установлених управлінським аналізом, дозволить сучасному менеджменту такого підприємства передбачити та забезпечити результативні заходи щодо збалансованого використання виробничих ресурсів.

Ключові слова: виробниче підприємство, управлінський облік, управлінський аналіз, менеджмент, збалансоване використання виробничих ресурсів.

Постановка проблеми. В процесі еволюції та реформування облікової системи виникає необхідність використання виробничим підприємством методики комплексного аналізу фінансової звітності для визначення його основних техніко-економічних показників, зокрема: фінансової стійкості, ефективності діяльності, ділової активності, інвестиційної привабливості тощо. Серед завдань адміністрування виробничих процесів - забезпечення не тільки раціонального використання виробничих ресурсів з метою прибутковості бізнесу, але й створення умов для збалансованого соціально-економічного та екологічного господарювання.

Сучасний багатоваріативний економічний аналіз за методами дослідження класифікується на фінансовий, управлінський та операційно-вартісний аналіз.

Фінансовий аналіз, як правило, проводиться на основі фінансо- 
вої звітності і включає такі питання, як аналіз основних фінансових результатів, рентабельності виробництва, фінансової стійкості та надійності, ділової активності, ліквідності, платоспроможності та ін.

Управлінський аналіз представляє собою систему спеціальних знань, пов'язану з дослідженням ресурсів підприємства з урахуванням його можливостей, що складаються під впливом об'єктивних і суб'єктивних чинників. Управлінський аналіз охоплює ширше коло аналітичних процедур господарської діяльності виробничого підприємства, базується не тільки на даних фінансової звітності, але й аналітичних даних бухгалтерського обліку, не тільки констатує факт, але й результати роботи підприємства, виявляючи причинно-наслідкові залежності.

Операційно-вартісний аналіз підприємства дає змогу визначити галузеву спеціалізацію діяльності, місце підприємства у системі госпрозрахункових відносин, можливості, форми та перспективи взаємовідносин з іншими контрагентами цієї системи. Крім того, операційно-вартісний аналіз дає змогу оцінити ефективність та доцільність функцій, які виконує підприємство [1].

Аналіз останніх досліджень та публікацій. Значний вклад у дослідження проблем теорії та методології економічного аналізу 3 використанням даних обліку та фінансової звітності підприємств внесли наступні науковці: Бартош О.М. [2], Білик М.Д. [3], Ф.Ф. Бутинець [4], Гоголь Т.А. [5], Грабовецький Б.Є. [6], Лисенко А.М. [7], Олійник О.В. [8] та ін.

Незважаючи на численні наукові розробки, проблема вибору виду економічного аналізу для розкриття фінансових результатів господарської діяльності, який би враховував специфіку виробничих підприємств, їх галузеві організаційно-економічні особливості, залишається не вирішеною. Це свідчить про актуальність питання, зумовлює напрям дослідження в науковому і практичному аспектах.

Метою і завданням дослідження $€$ оцінка результативності застосування економічного аналізу, окремо його складової - управлінського аналізу для виробничих підприємств на етапах формування збалансованого використання виробничих ресурсів з метою прийняття виважених адміністративних рішень.

Виклад основного матеріалу. Враховуючи міжнародну практику аналізу результатів діяльності бізнес-структур, метою управлінського аналізу є отримання ключових (найбільш інформативних) параметрів, що дають об'єктивну і найбільш точну картину економічного, господарського стану та фінансових результатів діяльності підприємства. Саме цей вид аналізу найбільш повно дозволяє виявити причини змін окремих явищ, оптимізувати структуру активів, капіталу та 
зобов'язань, виявити резерви активно-пасивних операцій, визначити резерви підвищення ефективності підприємницької діяльності підприємства в цілому.

Система цілей управлінського аналізу - це:

- оцінка місця підприємства в даному сегменті бізнесу; визначення організаційно-технічних можливостей підприємства; оцінка конкурентоспроможності продукції, місткості ринку;

- аналіз ресурсних можливостей збільшення обсягу виробництва і продажів за рахунок кращого використання засобів праці, предметів праці, трудових і фінансових ресурсів;

- аналіз можливих результатів виробництва і реалізації продукції та шляхи прискорення процесів виробництва та продажу;

- прийняття рішення щодо асортименту і якості продукції, запуску у виробництво нових зразків продукції;

- розробка стратегії управління витратами на виробництво за відхиленнями, за центрами витрат, відповідальності;

- вибір політики ціноутворення;

- аналіз взаємозв'язку обсягу продажів, витрат і прибутку з метою управління беззбитковістю виробництва [8; 9].

Мети аналізу досягають у результаті вирішення певного взаємозалежного набору аналітичних завдань через конкретизацію цілей аналізу з урахуванням організаційних, інформаційних, технічних і методичних можливостей його проведення.

Для вдосконалення існуючих методик комплексного економічного аналізу фінансових результатів виробничого підприємства, пропонуємо наступні етапи систематизації аналітичних процедур:

І. Постановка оптимізаційних завдань: вивчення об'єкта дослідження, специфіки його діяльності, цілей економічного аналізу фінансової звітності, завдань аналізу (за обліково-аналітичним та управлінськими напрямками).

II. Визначення видів аналізу та аналітичних процедур, за якими буде проводитися обробка інформації на етапах збору, узагальнення та передачі ії користувачам; інформаційних джерел (в розрізі показників, що формують доходи/витрати); робочих документів, внутрішніх форм звітності (в т.ч. за управлінським аналізом - внутрішньої фінансової та управлінської звітності).

III. Визначення методики оцінювання фінансового результату діяльності за показниками доходів і витрат підприємства (відповідно до класифікації фінансових результатів як об'єктів обліку).

IV. Узагальнення та інтерпретація причинно-наслідкового характеру динаміки отриманих показників з подальшим формулюванням 
висновків та пропозицій щодо об'єктів дослідження.

V. Формування висновків про перспективну та прогнозну діяльність, їі ресурсного забезпечення на засадах збереження позитивної динаміки економічних показників, соціального захисту трудових ресурсів та екологічної безпеки операційної діяльності.

Варто відмітити, що методика аналізу Звіту про фінансові результати суб'єктів малого підприємництва (СМП) на сьогодні не є достатньо уніфікованою з аналогічною формою фінансової звітності для інших підприємств. Відтак, співставляти результати аналізу господарської діяльності СМП та інших підприємств (навіть з використанням аналогічних методичних підходів) не коректно: розрахунок показників Форми № 2м «Звіт про фінансові результати» має дещо відмінний алгоритм у порівнянні з відповідними розрахунками Форми 2 «Звіт про фінансові результати (Звіт про сукупний доход)» для інших підприємств.

Зазначене унеможливлює: здійснення аналізу за видами доходів / витрат, прибутку у розрізі різних видів діяльності (зокрема, основною та іншою реалізацією); виокремлення сум доходів / витрат за об'єктами виникнення, напрямками збуту, рівнями контрольованості тощо; аналіз прибутку / збитку від різних видів діяльності, в тому числі - неосновної реалізації, позареалізаційних доходів; розрахунок відносних показників рентабельності та прибутковості за видами продукції, формами оплати (в першу чергу, за операціями в іноземній валюті) тощо. Для комплексної оцінки показників фінансової звітності підприємств пропонуємо використовувати наступну систему показників (рис. 1).

Модель використання аналітичної інформації для прийняття економічно обґрунтованих рішень управлінським персоналом малих, середніх та великих підприємств враховує неоднаковий інформаційний інтерес різних категорій користувачів у фінансовій та аналітичній інформації (рис. 2).

Актуалізується необхідність створення ефективного механізму управління діяльністю виробничого підприємства, що можливо лише за наявності ефективної інформаційної системи, кінцевою метою функціонування якої $€$ результативний за оцінкою менеджменту інформаційний продукт. Саме тому розв'язання конкретних проблем в управлінні підприємством вимагає побудови чіткої системи управлінського обліку, який включає елементи планування та прогнозування в поєднанні з аналізом фактичних показників фінансової звітності. 


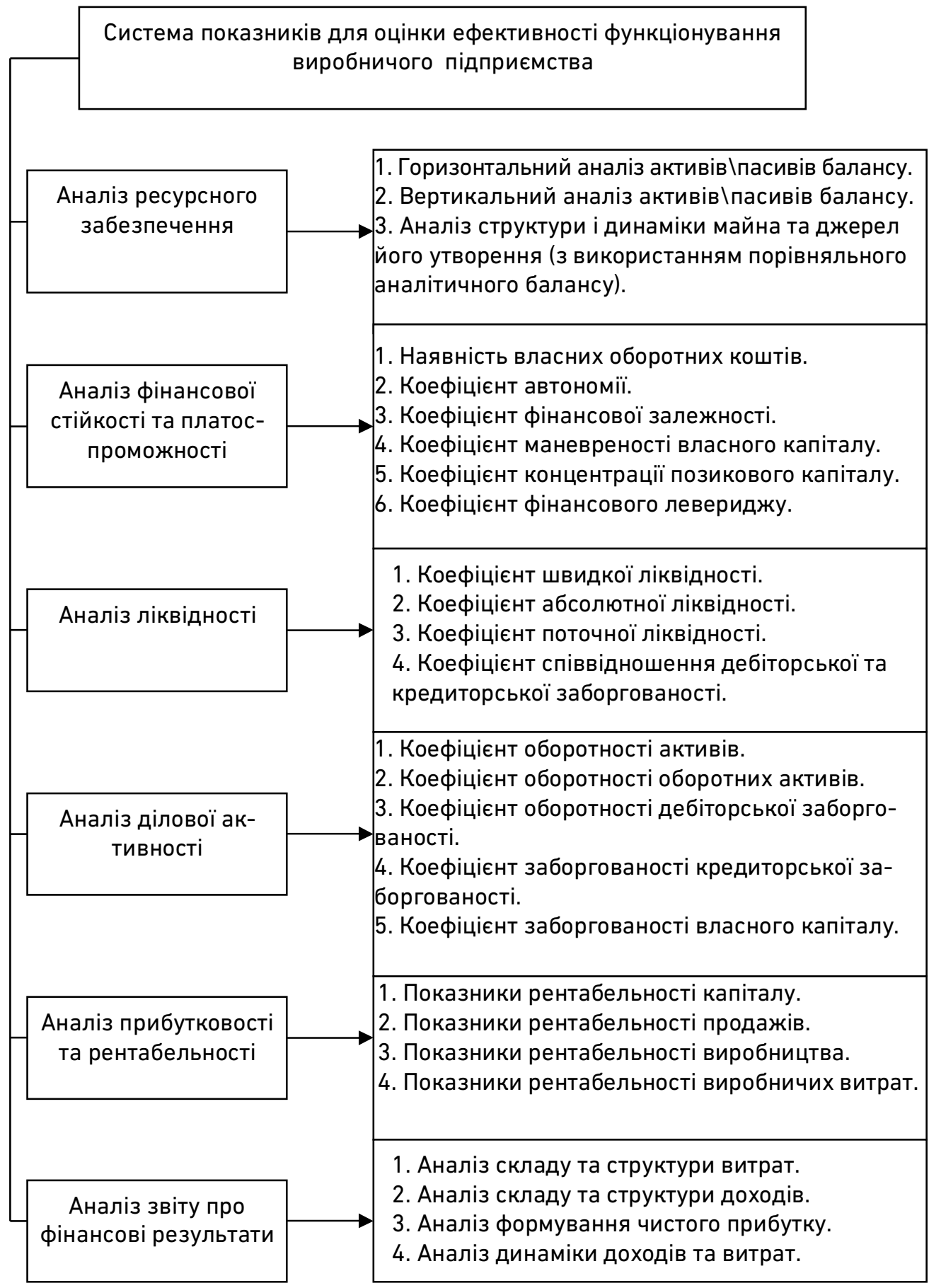

Рис. 1. Комплексна оцінка показників фінансової звітності підприємства (систематизовано на основі: $[2 ; 4 ; 5 ; 6 ; 10]$ ) 


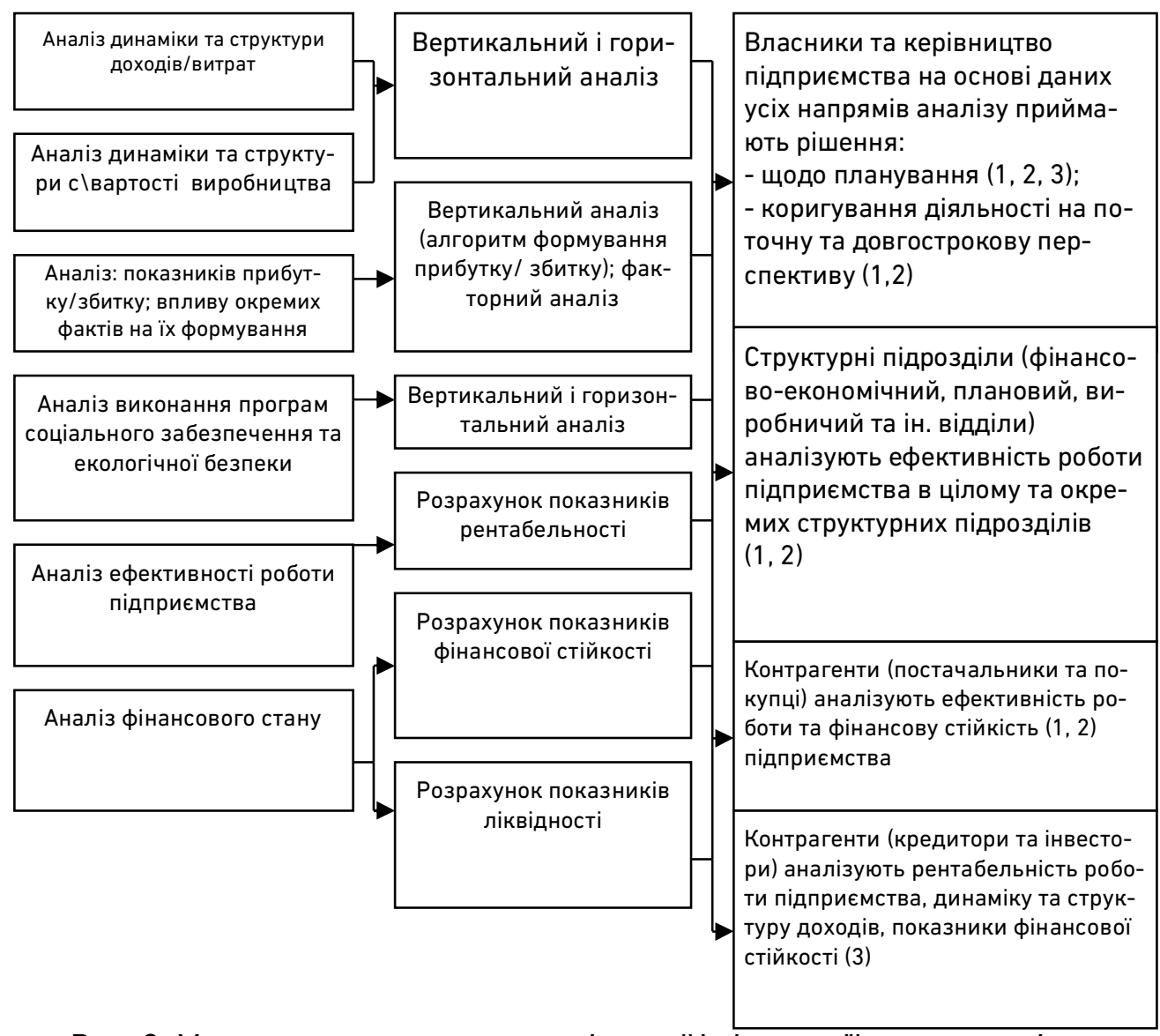

Рис. 2. Модель використання аналітичної інформації для управління промисловим підприємством: 1 - великі підприємства; 2 - середні підприємства; 3 - малі підприємства (розроблено з використанням та узагальненням $[2 ; 7 ; 8])$

Завдяки аналітичній побудові рахунків дані управлінського обліку дають можливість використовувати кількісні показники для визначення: вартісної оцінки активів та пасивів за центрами відповідальності та по підприємству в цілому; прибутковості за видами діяльності підприємства; життєвого циклу продуктів та послуг, їх продажу, оптимальні ціни; прибутковості (або навпаки - збитковості) окремих підрозділів виробничого підприємства; клієнтської бази, аналізу діяльності кожного клієнта та прибутковості окремих клієнтів.

У міжнародній практиці забезпечення системного контроллінгу для підвищення ефективності управління ресурсами, аналізу прибутковості окремих сфер бізнесу, моніторингу ризиків, інформаційного забезпечення бюджетування створюються центри відповідальності (ЦВ) - сфери діяльності, в межах яких встановлюється особиста відповідальність його керівника за показники діяльності, які він контролює $[2 ; 7 ; 11]$. 
В Україні на виробничих підприємствах функціональні центри відповідальності (ЦВ) як організаційна ланка управлінського обліку поширені досить мало. Функції управління за діяльністю окремого сегменту виробництва в зв'язку з незначним обсягом діяльності покладаються на власника підприємства, його директора чи бухгалтера. Разом з тим, відсутність окремих підрозділів на підприємстві не $є$ перешкодою до створення ЦВ. Зарубіжний досвід демонструє позитивну тенденцію створення у фінансовій структурі підприємства наступних типів центрів відповідальності:

- центр витрат - сфера діяльності підприємства, керівник якої відповідає тільки за витрати;

- центр доходів - сфера діяльності підприємства, керівник якої відповідає за отримання доходів;

- центр прибутку - сфера діяльності підприємства, керівник якої відповідає одночасно за витрати і доходи підрозділу;

- центр інвестицій - структурний сфера діяльності підприємства, керівник якої відповідає не тільки за витрати і доходи, але і за ефективність використання інвестицій [11].

Характеристика різних ЦВ наведена в табл. 1.

Таблиця 1

Характеристика центрів відповідальності*

\begin{tabular}{|c|c|c|c|c|}
\hline \multirow[b]{2}{*}{ Фактори } & \multicolumn{4}{|c|}{ Тип центру відповідальності } \\
\hline & $\begin{array}{l}\text { Центр } \\
\text { витрат }\end{array}$ & $\begin{array}{c}\text { Центр } \\
\text { доходів }\end{array}$ & $\begin{array}{c}\text { Центр } \\
\text { прибутку }\end{array}$ & $\begin{array}{c}\text { Центр } \\
\text { інвестицій }\end{array}$ \\
\hline $\begin{array}{l}\text { Контролюється } \\
\text { менеджментом } \\
\text { центру }\end{array}$ & Витрати & Доходи & $\begin{array}{l}\text { Витрати, } \\
\text { доходи }\end{array}$ & $\begin{array}{c}\text { Витрати, } \\
\text { доходи і } \\
\text { суттєвий } \\
\text { контроль за } \\
\text { фінансовими } \\
\text { інвестиціями }\end{array}$ \\
\hline $\begin{array}{l}\text { Не } \\
\text { контролюється } \\
\text { менеджментом } \\
\text { центру }\end{array}$ & $\begin{array}{c}\text { Доходи, } \\
\text { капітальні } \\
\text { інвестиції }\end{array}$ & $\begin{array}{c}\text { Витрати, } \\
\text { капітальні } \\
\text { інвестиції }\end{array}$ & $\begin{array}{c}\text { Інвестиції в } \\
\text { запаси, } \\
\text { капітальні } \\
\text { інвестиції }\end{array}$ & $\begin{array}{l}\text { Нефінансові } \\
\text { інвестиції }\end{array}$ \\
\hline $\begin{array}{l}\text { Вимірюється } \\
\text { системою } \\
\text { аналітичних } \\
\text { рахунків центру }\end{array}$ & $\begin{array}{c}\text { Оцінка } \\
\text { виконання } \\
\text { планових } \\
\text { показників } \\
\text { витрат, їх } \\
\text { оптимізації }\end{array}$ & $\begin{array}{c}\text { Оцінка } \\
\text { виконання } \\
\text { доходів } \\
\text { відношенню } \\
\text { до планових } \\
\text { показників }\end{array}$ & $\begin{array}{c}\text { Оцінка } \\
\text { формування } \\
\text { прибутку, } \\
\text { виконання } \\
\text { планових } \\
\text { показників }\end{array}$ & \begin{tabular}{|} 
Рентабельність \\
інвестицій по \\
відношенню до \\
заданого \\
значення \\
(бюджетного \\
рівня)
\end{tabular} \\
\hline
\end{tabular}

*Узагальнено автором з використанням інформації $[4 ; 6 ; 7 ; 8]$

Калькулювання собівартості продукції на промислових підприємствах здійснюється відповідно до П(С)БО 16 «Витрати» [12], Мето- 
дичних рекомендацій з формування собівартості продукції, робіт, послуг у промисловості та самостійно розроблених методик [13].

У вітчизняній та зарубіжній практиці бухгалтерського та управлінського обліку використовують більше десятка традиційних методів калькулювання та обліку витрат, серед яких: позамовний, попроцесний, нормативний, фактичний та інші методи.

Зазначені методи орієнтовані здебільшого на виробничий етап життєвого циклу продукту, тому досить часто довиробничі і післявиробничі витрати не співвідносяться з продуктом, який $€$ джерелом їх виникнення. Як наслідок, менеджери отримують необ'єктивну інформацію стосовно собівартості продукту, що може бути причиною прийняття неправильного управлінського рішення.

Підвищення вимог до надійності показника собівартості продукції, поряд з дієвістю управлінського аналізу, зумовлює впровадження нових (прогресивних) методів калькулювання собівартості продукції (табл. 2).

Якщо великі підприємства мають додатковий резерв у формі так званого «ефекту масштабу» (зниження питомих постійних витрат, що припадають на одиницю продукції, із зростанням рівня діяльності), то малий бізнес за своєю організаційною суттю не може дозволити собі суттєвого нарощування обсягів виробництва без додаткових капіталовкладень. Для вирішення питання необхідно шукати нетрадиційні підходи до управління фінансовими результатами своєї діяльності. Останнім часом вітчизняні підприємства (зокрема великий і середній бізнес) все частіше практикують один із сучасних видів аналізу - ABC-ана́ліз. Методика ABC-аналізу дозволяє класифікувати бізнес-ресурси суб'єкта залежно від їхньої значущості. В основі класифікації лежить принцип Парето, аксіомою якого $є$ твердження: надійний контроль 20\% позицій дозволяє на $80 \%$ контролювати систему [15].

Інформація, отримана в результаті ABC-аналізу, може допомогти виявити можливості збільшення прибутковості. Наприклад, АВС часто показує, що виробництво дрібносерійної продукції $\epsilon$ більш дорогим і відповідно - менш прибутковим при існуючому рівні цін. Отримавши таку інформацію, можна припинити виробництво таких продуктів, направивши ресурси на більш прибуткові продукти. Разом з тим, доцільно спробувати змінити організацію дрібносерійного виробництва для зменшення собівартості. Метод АВС ідентифікує процеси менеджменту, варті першочергових змін та модернізацій. 
Таблиця 2

Прогресивні методи калькулювання собівартості продукції

\begin{tabular}{|c|c|}
\hline $\begin{array}{c}\text { Метод } \\
\text { калькулювання }\end{array}$ & Коротка характеристика методу \\
\hline $\begin{array}{l}\text { АВС-костинг } \\
\text { (activity - based } \\
\text { costing) }\end{array}$ & $\begin{array}{l}\text { Ґрунтується на принципі поділу витрат на прямі і } \\
\text { накладні. При чому непрямі витрати } \\
\text { розподіляються не пропорційно певній базі (як при } \\
\text { традиційних методах), а за допомогою індексу- } \\
\text { розподілювача - фактора, що має причинно- } \\
\text { наслідковий зв'язок з витратами (наприклад: } \\
\text { людино-години, машино-години, площі офісних і } \\
\text { виробничих приміщень тощо) }\end{array}$ \\
\hline Директ-к & $\begin{array}{l}\text { Обчислення собівартості тільки на основі прямих } \\
\text { (змінних) виробничих витрат }\end{array}$ \\
\hline $\begin{array}{l}\text { Абзорпшен- } \\
\text { костинг }\end{array}$ & $\begin{array}{l}\text { Ґрунтується на тому, що до виробничої собівартості } \\
\text { включаються всі виробничі витрати незалежно від } \\
\text { того, } є \text { вони постійними чи змінними }\end{array}$ \\
\hline аргет-кос & $\begin{array}{l}\text { Застосовується на етапі проектування нового } \\
\text { виробу або модернізації застарілої продукції. } \\
\text { Даний метод розглядає собівартість не як } \\
\text { заздалегідь розрахований за нормативами } \\
\text { показник, як величину, до якої повинна прагнути } \\
\text { організація (цільова собівартість), щоб } \\
\text { запропонувати ринку конкурентний продукт }\end{array}$ \\
\hline Кайзен-к & $\begin{array}{l}\text { Зміст системи полягає у досягненні цільової } \\
\text { собівартості продукції та пошуку шляхів зниження } \\
\text { витрат до цільового рівня на стадії виробництва }\end{array}$ \\
\hline $\begin{array}{l}\text { Калькулювання } \\
\text { собівартості за } \\
\text { стадіями } \\
\text { життєвого циклу } \\
\text { продукту (life- } \\
\text { cycle costing (LCC) }\end{array}$ & $\begin{array}{l}\text { Вимірювання й накопичення всіх фактичних } \\
\text { витрат, пов'язаних із певним виробом упродовж } \\
\text { його життєвого циклу }\end{array}$ \\
\hline $\begin{array}{l}\text { Калькулювання за } \\
\text { системою «точно } \\
\text { в строк» (just - in } \\
\text { - time - JIT) }\end{array}$ & $\begin{array}{l}\text { Застосовується при відмові від виробництва } \\
\text { крупними партіями і створення безперервного - } \\
\text { поточного виробництва. Мета JIT - знищення } \\
\text { зайвих витрат і ефективне використання } \\
\text { виробничого потенціалу підприємства }\end{array}$ \\
\hline
\end{tabular}

${ }^{*}$ Складено на основі [ 7; 14]

Висновки. Результативність оперативного, перспективного та стратегічного управління потребує інформаційної бази, яка б за рівнем аналітики, цільової спрямованості, виваженості інтерпретації 
ідентифікованих тенденцій (змін, коригувань) уможливлювала залежність адміністрування бізнесу переважно від професійності управлінського персоналу, покладаючись на достовірність одержаних даних. Дослідження потреб виробничих підприємств на етапах євроінтеграції потребують більш широкого застосування інформаційного формату, в основі якого - аналітична обробка інструментарієм управлінського аналізу підготовлених за запитами менеджерів аналітичних даних управлінського обліку.

Щодо фінансових результатів, то визначальними для виробничих підприємств залишається оптимізація собівартості реалізації. Вибір та застосування того чи іншого методу обліку витрат вимагає від керівництва комплексного підходу до збору, аналізу, обробки фінансової інформації та відповідного програмного забезпечення облікового процесу, проте жоден із методів (традиційних чи інноваційних) не дає абсолютного релевантного результату. В ідеалі управлінська система має компонувати в собі основні доктрини бухгалтерського обліку з урахуванням сучасних міжнародних методик аналітичної обробки облікових даних.

1. Ефективність аналітичної роботи. URL: https://studme.com.ua/1417012010019/ekonomika/rol_mesto_upravlenches kogo_analiza_sisteme_upravleniya_predpriyatiem.htm (дата звернення : 03.10.2018). 2. Бартош О. М. Управлінський облік, як основа ефективної системи управління банком. Фінансовий простір. 2014. № 1(13). С. 36-42. URL: http://fp.cibs.ck.ua/files/1401/14bomuoj.pdf (дата звернення : 03.10.2018). 3. Білик М. Д., Білик Т. О. Фінансові результати діяльності малих підприємств: оцінка та прогнозування : монографія. Київ : ТОВ «ПанТот», 2012. 280 с. 4. Бутинець Ф. Ф., Чижевська Л. В., Герасимчук Н. В. Бухгалтерський управлінський облік : підручник. Житомир : ЖІTІ, 2000. 448 с. 5. Гоголь Т. А. Особливості методики фінансового аналізу підприємств малого бізнесу. Вісник Чернігівського державного технологічного університету. 2013. № 2 (66). С. 391-398. 6. Грабовецький Б. Є., Шварц І. В. Фінансовий аналіз та звітність : навчальний посібник. Вінниця : ВНТУ, 2011. 281 с. 7. Лисенко А. М., Недовоз Ю. Ю. Удосконалення методики проведення комплексного аналізу фінансової звітності малого підприємства URL: http://kntu.kr.ua/doc/zb_22(2)_ekon/stat_20_1/23.pdf (дата звернення : 03.10.2018). 8. Олійник О. В. Системний підхід до управління витратами. Стратегія економічного розвитку України. 2013. № 33. С. 258-264. 9. Іванова Т. Методологічні засади оцінювання показників ефективності діяльності малого бізнесу. Вісник Київського національного університету імені Тараса Шевченка. Економіка. 2013. № 134. С. 27-29. 10. Шевчук Н. А. Дослідження вітчизняних та зарубіжних методів управління собівартістю продукції. Сучасні проблеми економіки та підприємництво. 2011. Вип. 6. С. 219223. 11. Neil's Brock Copenhagen Business College. Kultorvet 2, Copenhagen 
K, Denmark, 2008. 250 p. 12. Положення (стандарт) бухгалтерського обліку 16 «Витрати», затверджено наказом Міністерства фінансів України № 318 від 31.12.1999р., із змінами і доповненнями, внесеними наказами Міністерства фінансів України № 1591 від 09.12.2011 р. URL: http://zakon2.rada.gov. ua/laws/show/z0027-00 (дата звернення : 03.10.2018). 13. Методичні рекомендації з формування собівартості продукції (робіт, послуг) у промисловості, затверджені наказом Міністерства промислової політики України від 09.07.2007 p. № 373. URL: http://www.ukraine.uapravo.net /data2008/.../ukr21347 (дата звернення : 03.10.2018). 14. Михайлишин Н. П., Мельник Н. Г. Прогресивні калькуляційні системи. Глобальні та національні проблеми економіки. 2015. Вип. 5. С. 1008-1012. 15. ABC-аналіз. Вікіпедія. URL: https://www.google.com.ua/search?еі (дата звернення : 03.10.2018).

\section{REFERENCES :}

1. Efektyvnist analitychnoi roboty. URL: https://studme.com.ua/1417012010019/ekonomika/rol_mesto_upravlenches kogo_analiza_sisteme_upravleniya_predpriyatiem.htm (data zvernennia : 03.10.2018). 2. Bartosh 0. M. Upravlinskyi oblik, yak osnova efektyvnoi systemy upravlinnia bankom. Finansovyi prostir. 2014. № 1(13). S. 36-42. URL: http://fp.cibs.ck.ua/files/1401/14bomuoj.pdf (data zvernennia : 03.10.2018). 3. Bilyk M. D., Bilyk T. O. Finansovi rezultaty diialnosti malykh pidpryiemstv: otsinka ta prohnozuvannia : monohrafiia. Kyiv : TOV «PanTot», 2012. 280 s. 4. Butynets F. F., Chyzhevska L. V., Herasymchuk N. V. Bukhhalterskyi upravlinskyi oblik : pidruchnyk. Zhytomyr: ZhITI, 2000. 448 s. 5. Hohol T. A. Osoblyvosti metodyky finansovoho analizu pidpryiemstv maloho biznesu. Visnyk Chernihivskoho derzhavnoho tekhnolohichnoho universytetu. 2013. № 2 (66). S. 391-398. 6. Hrabovetskyi B. Ye., Shvarts I. V. Finansovyi analiz ta zvitnist : navchalnyi posibnyk. Vinnytsia : VNTU, 2011. 281 s. 7. Lysenko A. M., Nedovoz Yu. Yu. Udoskonalennia metodyky provedennia kompleksnoho analizu finansovoi zvitnosti maloho pidpryiemstva URL: http://kntu.kr.ua/doc/zb_22(2)_ekon/stat_20_1/23.pdf (data zvernennia : 03.10.2018). 8. Oliinyk 0. V. Systemnyi pidkhid do upravlinnia vytratamy. Stratehiia ekonomichnoho rozvytku Ukrainy. 2013. № 33. S. 258-264. 9. Ivanova T. Metodolohichni zasady otsiniuvannia pokaznykiv efektyvnosti diialnosti maloho biznesu. Visnyk Kyivskoho natsionalnoho universytetu imeni Tarasa Shevchenka. Ekonomika. 2013. № 134. S. 27-29. 10. Shevchuk N. A. Doslidzhennia vitchyznianykh ta zarubizhnykh metodiv upravlinnia sobivartistiu produktsii. Suchasni problemy ekonomiky ta pidpryiemnytstvo. 
2011. Vyp. 6. S. 219-223. 11. Neils Brock Copenhagen Business College. Kultorvet 2, Copenhagen K, Denmark, 2008. 250 r. 12. Polozhennia (standart) bukhhalterskoho obliku 16 «Vytraty», zatverdzheno nakazom Ministerstva finansiv Ukrainy № 318 vid 31.12.1999 r., iz zminamy i dopovnenniamy, vnesenymy nakazamy Ministerstva finansiv Ukrainy № 1591 vid 09.12.2011 r. / Zakonodavstvo Ukrainy. URL: http://zakon2.rada.gov. ua/laws/show/z0027-00 (data zvernennia : 03.10.2018). 13. Metodychni rekomendatsii z formuvannia sobivartosti produktsii (robit, posluh) u promyslovosti, zatverdzheni nakazom Ministerstva promyslovoi polityky Ukrainy vid 09.07.2007 r. № 373. URL: http://www.ukraine.uapravo.net /data2008/.../ukr21347 (data zvernennia : 03.10.2018). 14. Mykhailyshyn N. P., Melnyk N. H. Prohresyvni kalkuliatsiini systemy. Hlobalni ta natsionalni problemy ekonomiky. 2015. Vyp. 5. S. 10081012. 15. ABC-analiz. Vikipediia. URL: https://www.google.com.ua/search?ei (data zvernennia : 03.10.2018).

Рецензент: д.е.н., професор Савіна Н. Б. (НУВГП)

Levytska S. O., Doctor of Economics, Professor, Sych D. M., Post-graduate Student (National University of Water and Environmental Engineering, Rivne)

\section{INFORMATIVITY OF ECONOMIC ANALYSIS IN THE SYSTEM OF MANAGEMENT ACCOUNT}

The article is devoted to the study of the practical application of the toolkit of the managerial analysis of the financial results of the production enterprises of Ukraine. The methodology and organization of this type of economic analysis for indicators of management accounting is generalized. The factors of the formation of the necessary level of detail of analytical procedures are revealed. Clarification of methodological differences in the preparation of the main forms of financial reporting on indicators of financial results (Form 2 «Statement of financial results»), that is typicaly for small businesses and for other production enterprises, are solved. The following issues are considered: the international practice of functioning of the centers of responsibility in the priority areas of business development; alternative methods of calculating the cost of finished products, the model of using analytical information for making economically justified decisions by the management of small, medium and large enterprises. The expediency of the ABC-analysis the methods of which allow to classify the firm's business resources depending on their significance is substantiated. Taking into account 
the international practice of achieving optimal cost, it is recommended to apply management analysis procedures in conjunction with modern costing methods, in particular: ABC-costing, direct-costing, absorption-costing, target costing, kaizen costing, calculating lifecycle costing (LCC), calculation by the system «just-in-time» (just-intime - JIT). The formation of balanced, operational and complete cause-and-effect trends established by management analysis will allow modern management of such an enterprise to envisage and ensure effective measures for the balanced use of production resources.

Keywords: production enterprise, management accounting, management analysis, management, balanced use of production resources.

Левицкая С. А., А.э.н., профессор, Сыч Д. М., аспирант (Национальный университет водного хозяйства и природопользования, г. Ровно)

\section{ИНФОРМАТИВНОСТЬ ЭКОНОМИЧЕСКОГО АНАЛИЗА В СИСТЕМЕ УПРАВЛЕНЧЕСКОГО УЧЕТА}

Статья посвящена изучению вопросов практического применения инструментария управленческого анализа финансовых результатов деятельности производственных предприятиятий Украины. Рассмотрены международная практика функционирования центров ответственности в разрезе приоритетных направлений развития бизнеса; альтернативные методы калькуляции себестоимости готовой продукции; модель использования аналитической информации для принятия экономически обоснованных решений руководством малых, средних и крупных предприятий. Обоснована целесообразность использования $\mathrm{ABC}$-анализа, методы которого позволяют классифицировать бизнес-ресурсы фирмы в зависимости от их значимости. Формирование взвешенных, оперативных и полных причинно-следственных тенденций за данными управленческого анализа позволит современному менеджменту такого предприятия предусмотреть и обеспечить результативные меры по сбалансированному использованию производственных ресурсов. Ключевые слова: производственное предприятие, управленческий учет, управленческий анализ, менеджмент, сбалансированное использование производственных ресурсов. 